\title{
Немченко А.В. \\ Понятие и содержание права личности на неприкосновенность жилища в российском уголовном судопроизводстве
}

Ростовский филиал ФГБОУВО «Российский государственный университет правосудия» (Россия, Ростов-на-Дону)

doi: 10.18411/trnio-11-2021-255

Научный руководитель: Коблева М.М.

\section{Аннотация}

В статье исследуется право личности на неприкосновенность жилища в уголовном судопроизводстве. В связи с отсутствием законодательного определения данного личного права, анализируются категории «жилище», «неприкосновенность» и «неприкосновенность жилища». Определяется, что понятие жилище наиболее полно раскрывается в УПК РФ.
Ключевые
слова:
уголовное
судопроизводство,
личность,
право,

неприкосновенность жилища.

\section{Abstract}

The article examines the individual's right to the inviolability of the home in criminal proceedings. Due to the lack of a legislative definition of this personal right, the categories "dwelling", "inviolability" and "inviolability of the home" are analyzed. It is determined that the concept of dwelling is most fully disclosed in the Code of Criminal Procedure of the Russian Federation.

Keywords: criminal proceedings, personality, law, home inviolability.

В российской правовой системе право на неприкосновенность жилища появилось еще в $\mathrm{X}$ в. и установило возможность применения силы в отношении лица, вторгшегося в чужое владение. Так, согласно Русско-Византийскому договору 911 г. «вор, пойманный при краже жилища, мог быть убит проживающими там» [1].

Сегодня право на неприкосновенность жилища получило закрепление в статье 25 Конституции РФ, которая гласит: «Жилище неприкосновенно. Никто не вправе проникать в жилище против воли проживающих в нем лиц иначе как в случаях, установленных федеральным законом, или на основании судебного решения» [2]. Кроме того, норма о неприкосновенности жилища нашла отражение и в отраслевом законодательстве. Так, согласно ст. 12 действующего Уголовно-процессуального кодекса Российской Федерации «Осмотр жилища производится только с согласия проживающих в нем лиц или на основании судебного решения, за исключением случаев, предусмотренных ч. 5 ст. 165 УПК РФ. Обыск и выемка в жилище могут производиться на основании судебного решения, за исключением случаев, предусмотренных ч. 5 ст. 165 УПК РФ» [3]. Примечательно, что в Советском союзе право лица на неприкосновенность жилища в уголовном судопроизводстве было гарантировано в ст. 12 УПК РСФСР 1960 г.: «никто не имеет права без законного основания войти в жилище против воли проживающих в нем лиц» [4].

Следует отметить, что неприкосновенность жилища является одним из международно-правовых принципов и закреплена во всех основных актах международного права (например, ст. 12 Всеобщей декларации прав человека, ст. 17 Международного пакта о гражданских и гражданских правах, ст. 8 Конвенции о защите прав человека и основных свобод).

К сожалению, УПК РФ не в полном объеме раскрывает механизм реализации принципа неприкосновенности жилища в уголовном судопроизводстве, что порождает ряд сложностей правоприменения. В связи с чем, необходимо раскрыть понятие таких категорий, как «жилище», «неприкосновенность» и «неприкосновенность жилища». При этом, следует отметить, что из указанных категорий законодательно закреплено только понятие «жилища». 
Итак, центральным вопросом права на неприкосновенность жилища является понимание самого термина «жилище». Термин «жилище» законодательно закреплён и в уголовном, и в уголовно-процессуальном, и в жилищном законодательстве, однако трактуется он по-разному.

Так, согласно ч. 2 ст. 15 Жилищного кодекса Российской Федерации «Жилым помещением признается изолированное помещение, которое является недвижимым имуществом и пригодно для постоянного проживания граждан (отвечает установленным санитарным и техническим правилам и нормам, иным требованиям законодательства)[5].

Согласно примечанию к ст. 139 Уголовного кодекса Российской Федерации «Под жилищем понимаются индивидуальный жилой дом с входящими в него жилыми и нежилыми помещениями, жилое помещение независимо от формы собственности, входящее в жилищный фонд и пригодное для постоянного или временного проживания, а равно иное помещение или строение, не входящие в жилищный фонд, но предназначенные для временного проживания» [6].

И, наконец, п. 10 ст. 5 УПК РФ определяет жилище, как «индивидуальный жилой дом с входящими в него жилыми и нежилыми помещениями, жилое помещение независимо от формы собственности, входящее в жилищный фонд и используемое для постоянного или временного проживания, а равно иное помещение или строение, не входящее в жилищный фонд, но используемое для временного проживания» [3].

Из содержания приведенных определений следует, что наиболее полное определение термина «жилище» дает УПК РФ, включая в него любое помещение, используемое лицом для проживания. Следовательно, принцип неприкосновенности жилища должен распространяться на все помещения (любые), которые используются лицом в целях проживания, и, соответственно, при проведении осмотра, обыска и выемки таких помещений всегда необходимо решение суда. Подтверждением данного вывода служит Постановление Пленума Верховного Суда Российской Федерации от 1 июня 2017 г. № 19 г. «О практике рассмотрения судами ходатайств о производстве следственных действий, связанных с ограничением конституционных прав граждан (статья 165 УПК РФ)», согласно п. 8 которого: «при разрешении ходатайств о производстве осмотра в жилище при отсутствии согласия проживающих в нем лиц, обыска и (или) выемки в жилище (пункты 4 и 5 части 2 статьи 29 УПК РФ) судам следует исходить из понятия жилища, содержащегося в пункте 10 статьи 5 УПК РФ» [7]. Кроме того, как отмечает Конституционный Суд РФ, «условием отнесения нежилых помещений и строений, не входящих в жилой фонд, к жилищу является факт их использования для временного проживания» [8].

Что касается категории «неприкосновенность», то согласно Толковому словарю С.И. Ожегова, «неприкосновенный - это 1. Сохраняемый в целости, защищенный от всякого посягательства со стороны кого-н. Музейные ценности не прикосновенны. 2. Не подлежащий расходованию. Н. фонд. Н. запас (сохраняемый на самый крайний случай). II сущ. неприкосновенность, -и, ж. Н. личности (право гражданина на государственную охрану и защиту от противоправных посягательств на его личность; спец.)» [9, с. 765].

Следует отметить, что понятие «неприкосновенность» в большей степени используется в конституционном праве и является составной частью правового статуса гражданина и отдельных категорий должностных лиц. Правовой статус включает в себя систему прав, свобод и обязанностей, а также их конкретное выражение. Как известно, каждый человек наделяется определенной степенью свободы в силу свободы, однако, данная свобода относительная, поскольку при реализации своих прав индивидуум должен учитывать интересы и других лиц, которые также являются составной часть общества. Как справедливо отмечает А.Д. Фатикова «свобода личности выражается в способности и возможности сознательно-волевого выбора своей модели поведения, в определенной независимости человека от внешних условий и обстоятельств, не забывая при этом, что закон всегда является частичным ограничением индивидуальной свободы, что необходимо для совместного сосуществования свободных граждан» [10, с. 50]. 
Среди классификаций прав личности, самой распространений является по сферам общественной жизни, где выделяются личные, политические, социально-экономические и культурные. В свою очередь личные права - это права, принадлежащие каждому от рождения и независящие от принадлежности к государству и не зависят от государства. Данную группу прав называют «прирожденными и неотчуждаемыми для каждого человека, независимо от его гражданства, пола, возраста, расы, национальности или религии» [10, с. 50]. личности.

Таким образом, неприкосновенность жилища составляет группу личных прав

Однако, в науке встречаются различные определения категории «неприкосновенность жилища». Так, П.Ю. Тюрин определяет неприкосновенность жилища как «особое состояние личного, индивидуального и недоступного для посторонних места, объекта, призванного обеспечивать, защищать и гарантировать протекание необходимых естественных процессов, целостность и сохранность информации напрямую. затрагивающие личную (интимную) сторону жизни человека, личную и семейную тайну на данной закрытой территории (жилище); гарантия от их (секретов) нежелательного приобретения различными незаконными методами и способами как у частных лиц, так и у государства в лице его органов и учреждений» [11, с. 232].

В свою очередь, В.И. Червонюк считает, что «неприкосновенность жилища - это право человека на государственную охрану арендуемого или принадлежащего ему на праве собственности жилого или хозяйственного помещения от неправомерного вмешательства как должностных лиц, так и отдельных граждан» [12, с. 146].

По нашему мнению, неприкосновенность жилища - это гарантированное право личности на осуществление своей личной (частной) жизни в пространстве, закрытом от третьих лиц, на свободное определение своего образа жизни, а также функция по защите личности от незаконного и необоснованного вторжение в жилище со стороны государственных органов и должностных лиц.

По справедливому мнению, Х.П. Шептуховой «в содержании понятия «право на неприкосновенность жилища» необходимо выделить внутреннюю и внешнюю составляющие. Внутренней составляющей «неприкосновенности жилища» будет то, что гражданин сам формирует свой образ жизни, семейные отношения, отношения с другими людьми в этом жилище, он сам обеспечивает уровень конфиденциальности информации о своей личной жизни. Внешний компонент состоит в защитной функции, обеспечивающей защиту рассматриваемого органа от вторжения в жилище государственных органов, должностных лиц, ведущих производство по делу» [12, с. 128].

Таким образом, с учетом анализа категорий «жилища», «неприкосновенность» и «неприкосновенность жилища» представляется возможным сформулировать следующее определение права личности на неприкосновенность жилища в уголовном судопроизводстве:

«это гарантированная нормами как международного права, так и внутреннего законодательства, возможность осуществления своей личной (частной) жизни в пространстве, закрытом от третьих лиц, свободного определения своего образа жизни, а также закреплённая в законе и обеспеченная государством функция по защите личности от незаконного и необоснованного вторжение в жилище со стороны государственных органов и должностных лиц.

$$
* * *
$$

1. Русско-Византийский договор 911 г. Эл. ресурс. режим доступа: https://www.prlib.ru/history/619503 (дата обращения: 16.08.2021 г.)

2. Конституция Российской Федерации (принята всенародным голосованием 12.12 .1993 с изменениями, одобренными в ходе общероссийского голосования 01.07.2020) // СПС «Консультант плюс»

3. Уголовно-процессуальный кодекс Российской Федерации от 18.12.2001 №174-Ф3 (ред. от 01.07.2021) // Собрание законодательства РФ. 24.12.2001. № 52 (ч. І). Ст. 4921. 
4. Уголовно-процессуальный кодекс РСФСР (утв. ВС РСФСР 27.10.1960) (утратил силу) // Ведомости ВС РСФСР. 1960. № 40. Ст. 592.

5. Жилищный кодекс Российской Федерации от 29.12.2004 №188-Ф3 (ред. от 28.06.2021) // Собрание законодательства РФ. 03.01.2005. № 1 (часть 1). Ст. 14.

6. Уголовный кодекс Российской Федерации от 13.06.1996 № 63-Ф3 (ред. от 01.07.2021) // Собрание законодательства РФ. 17.06.1996. № 25. Ст. 2954.

7. Постановление Пленума Верховного Суда РФ от 01.06.2017 № 19 «О практике рассмотрения судами ходатайств о производстве следственных действий, связанных с ограничением конституционных прав граждан (статья 165 УПК РФ)» // Бюллетень Верховного Суда РФ. 2017. № 7.

8. Определение Конституционного Суда РФ от 12.05.2005 № 166-О «Об отказе в принятии к рассмотрению жалобы гражданки Котовой Светланы Евгеньевны на нарушение ее конституционных прав пунктом 10 статьи 5 Уголовно-процессуального кодекса Российской Федерации» // Вестник Конституционного Суда РФ. 2005. № 6.

9. Ожегов С.И. Толковый словарь русского языка / Под ред. проф. Л.И. Скворцова. - 28-е изд. перераб. - М.: Мир и образование, 2014.

10. Фатикова А.Д. Механизм реализации принципа неприкосновенности жилища в уголовном судопроизводстве: Дисс. к.ю.н. - Казань, 2010.

11. Тюрин П.Ю. Конституционное право человека и гражданина на неприкосновенность жилища в РФ: Дис... канд. юрид. наук. - Саратов, 2002.

12. Червонюк В.И. Конституционное право России: учебное пособие / В.И. Червонюк. - М.: ИНФРА - М, 2003.

13. Шептунова Х.П. К вопросу о понятиях «неприкосновенность жилища» и «принцип неприкосновенности жилища» в уголовном судопроизводстве // Вестник Оренбургского государственного университета. 2009. № 3 (97).

\section{Перминова А.C.}

Проблемы квалификации деяний, направленных на возбуждение суицидального поведения: анализ следственно-судебной практики

Центральный филиал ФГБОУ ВО «Российский государственный университет правосудия» (Россия, Воронеж)

doi: 10.18411/trnio-11-2021-256

Научный руководитель: Карташов И.И.

\section{Аннотация}

В статье акцентировано внимание на том, что невзирая на то, что в России в последнее время имеется положительная тенденция исследования проблематики уголовной ответственности за доведение до самоубийства, до сих пор остается достаточно широкий круг проблемных вопросов, как теоретической направленности, так и связанных с практической деятельностью следственных и судебных органов.

Ключевые слова: проблемы квалификации деяний, суицидальное поведение, следственная практика, судебная практика, возбуждение суицидального поведения.

\section{Abstract}

The article focuses on the fact that despite the fact that in Russia there has recently been a positive trend in the study of the problems of criminal responsibility for driving to suicide, there is still a wide range of problematic issues, both theoretical and related to the practical activities of investigative and judicial authorities.

Keywords: problems of qualification of acts, suicidal behavior, investigative practice, judicial practice, initiation of suicidal behavior.

С юридической точки зрения под самоубийством принято считать умышленное причинения вреда собственному здоровью с последствиями не совместимыми с жизнью [1]. По данным Всемирной организации здравоохранения (ВО3) на планете ежегодно совершается свыше 800 тыс. самоубийств, значительная часть - а это около 650 тыс. случаев - совершается лицами в возрасте до 30 лет [2]. Следует отметить, что суицид и суицидальные 